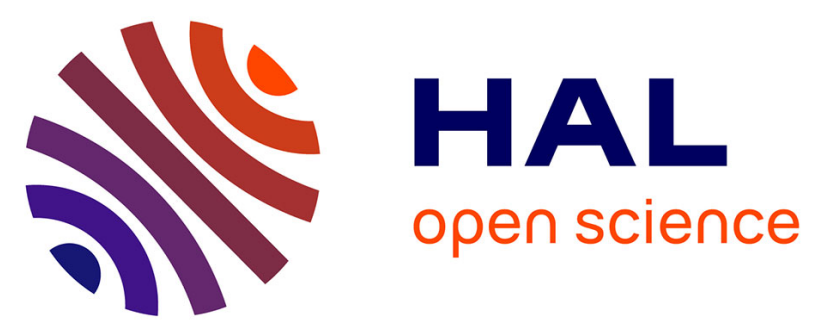

\title{
Critical water activity and amorphous state for optimal preservation of lyophilised lactic acid bacteria
}

Stéphanie Passot, Stéphanie Cenard, Inès Douania, Ioan Cristian Trelea, Fernanda Fonseca

\section{- To cite this version:}

Stéphanie Passot, Stéphanie Cenard, Inès Douania, Ioan Cristian Trelea, Fernanda Fonseca. Critical water activity and amorphous state for optimal preservation of lyophilised lactic acid bacteria. Food Chemistry, 2012, 132 (4), pp.1699-1705. 10.1016/j.foodchem.2011.06.012 . hal-01536691

\section{HAL Id: hal-01536691}

\section{https://hal-agroparistech.archives-ouvertes.fr/hal-01536691}

Submitted on 16 Jun 2017

HAL is a multi-disciplinary open access archive for the deposit and dissemination of scientific research documents, whether they are published or not. The documents may come from teaching and research institutions in France or abroad, or from public or private research centers.
L'archive ouverte pluridisciplinaire HAL, est destinée au dépôt et à la diffusion de documents scientifiques de niveau recherche, publiés ou non, émanant des établissements d'enseignement et de recherche français ou étrangers, des laboratoires publics ou privés. 
4 Stéphanie Passot ${ }^{*}$, Stéphanie Cenard, Inès Douania, Ioan Cristian Tréléa, Fernanda Fonseca UMR 782 Génie et Microbiologie des Procédés Alimentaires, AgroParisTech / INRA,

${ }^{*}$ Corresponding author. Tel. : +33130815940; fax : +33130815597.

E-mail address : spassot@,grignon.inra.fr (S. Passot) 


\section{Abstract (150 words maxi)}

12 The aim of this study was to investigate the influence of the water activity on the stability of

13 lyophilized lactic acid bacteria, especially in the solid glassy region. Lactobacillus bulgaricus

14 CFL1 was co-lyophilized with sucrose and stored under controlled relative humidity at $25^{\circ} \mathrm{C}$.

15 Glass transition temperature (Tg), water activity, water content and loss of specific

16 acidification activity during storage were determined. The rates of bacteria degradation were

17 analyzed as a function of water activity and as a function of the temperature difference 18 between storage temperature and Tg. Above Tg, the degradation rate appeared related to the

19 physical changes of the amorphous matrix. Below Tg, the optimal stability of the lyophilized

20 bacteria was observed in the intermediate water activity range $0.1-0.214$. An integrated 21 analysis of the relationships between water activity, $\mathrm{Tg}$, water content and biological activity 22 appeared as a promising approach for optimizing the freeze-drying process and predicting the 23 storage stability.

26 Keywords: water activity, lactic acid bacteria, freeze-drying, glass transition, storage

27 stability, lyophilisation, residual moisture 


\section{Introduction}

Lactic acid bacteria (LAB) are widely used as starters for manufacturing cheeses, fermented milks, meats, vegetables and breads products. Several species have been shown to exhibit probiotic properties i.e. positive effects on human health (Naidu et al., 1999). The preparation of starter cultures requires production and maintenance techniques that maximise viability, activity and storage stability of bacterial cells. While frozen concentrates of lactic acid bacteria exhibit maximal survival in liquid nitrogen, the expense of these storage conditions limits the use of this method. Freeze-drying (or lyophilisation) appears as an alternative method for long time preservation of bacteria and yeasts.

When lactic acid bacteria are used as components of commercial starters, they are often freeze-dried in the presence of sugars and embedded in amorphous matrices (Abadias et al., 2001; Carvalho et al., 2004; Castro et al., 1997; Champagne et al., 1991; Leslie et al., 1995; Meng et al., 2008). The bacteria are so stabilized against physical and/or chemical degradation during dehydration and storage (Santivarangkna et al., 2008). The stability of bacteria in an amorphous sugar matrix is considered to depend mainly on the following two factors: the sugar it self and the physical state of the matrix. The extent of the stabilizing effect of the sugar varies with the specific sugar used (Kurtmann et al., 2009b; Miao et al., 2008; Zayed \& Roos, 2004; Zhao \& Zhang, 2005). For instance, lactose is currently used as protective sugar through the addition of skim milk. However, lactose as a reducing sugar reacts with milk proteins, thus inducing Maillard reaction (nonenzymatic browning). Nonreducing disaccharides such as sucrose or trehalose are reported to be among the most effective protective molecules for freeze-drying bacteria (Conrad et al., 2000; Crowe et al., 1988; Crowe et al., 1996). The other factor affecting bacteria preservation is the physical stability of the amorphous sugar matrix: when an amorphous sugar is exposed to high temperature or high humidity above the glass transition, various properties of the materials 
change resulting in subsequent loss of the stabilizing effect of the amorphous sugar (Crowe et al., 1998; Patist \& Zoerb, 2005; Pikal, 1999; Slade \& Levine, 1991; Sun \& Davidson, 1998). The most important changes are an exponential increase of molecular mobility and decrease of viscosity, which govern time-dependent structural changes such as collapse, sugar crystallisation and diffusion-controlled chemical reactions such as nonenzymatic browning (Buera \& Karel, 1995; Buera et al., 2005; Jouppila \& Roos, 1994a; Roos, 2002).

State diagrams have been proposed to describe the different region of the physical state of material and associated with sorption isotherms have often been related to the dried product quality and used for predicting the product stability during processing and storage (Fonseca et al., 2001; Roos, 1995). For instance, the critical water content and water activity values leading to physical changes of the amorphous material may be identified and used for process and storage design. When considering biological products such as proteins or bacteria, the effect of water on the solid state stability of glassy systems is complex, since water can play not only the role of plasticizer in a degradation process but also the role of reactant and solvent. These different roles of water suggest that progressively greater stability should be observed at lower moisture contents. The empirical rule "the drier, the better" is commonly used for designing dehydration process. However, some exceptions have been reported for dried proteins, viruses, bacteria (Breen et al., 2001; Chang et al., 2005b; Croyle et al., 2001; Greiff, 1970; Hsu et al., 1992; Pikal et al., 1992; Scott, 1958; Zayed \& Roos, 2004). Moreover, very few studies have investigated the effect of residual water content on the stability of dehydrated bacteria, especially in the glassy region.

Our objective was thus to deeper investigate the effect of moisture content and water availability on the stability of freeze-dried lactic acid bacteria and to propose a useful tool combining state diagram, sorption isotherm and bacterial biological activity for designing an optimal freeze-drying process. 


\section{Materials and methods}

\subsection{Production of lyophilized lactic acid bacteria}

The lactic acid bacteria strain, Lactobacillus delbrueckii sbsp. bulgaricus CFL1, was obtained from the stock culture of the Laboratoire de Génie et Microbiologie des Procédés Alimentaires (INRA, Thiverval-Grignon, France) and used for all experiments. Inocula were stored at $-80^{\circ} \mathrm{C}$. Cultures were grown in supplemented whey medium $(60 \mathrm{~g} / \mathrm{L}$ whey, $20 \mathrm{~g} / \mathrm{L}$ lactose, $5 \mathrm{~g} / \mathrm{L}$ yeast extract) in a 2,15 or 75 liters fermentor at $42^{\circ} \mathrm{C}$. The $\mathrm{pH}$ was controlled at 5.5 by addition of $1.44 \mathrm{M} \mathrm{NaOH}$. Cells were harvested by centrifugation $(17000 \times g, 30 \mathrm{~min}$, $4^{\circ} \mathrm{C}$ ) at the end of the exponential growth phase, when the $\mathrm{NaOH}$ consumption rate started to decrease. After an intermediate storage period for 30 minutes at $4^{\circ} \mathrm{C}$, concentrated cells were re-suspended at $4^{\circ} \mathrm{C}$ in a $1: 2$ cells/protective medium ratio. The protective medium was composed of $200 \mathrm{~g} / \mathrm{L}$ of sucrose and $0.15 \mathrm{M}$ of $\mathrm{NaCl}$. The final protected bacterial suspensions were aliquoted into $50 \mathrm{~mm}$ diameter stainless steel container $(15 \mathrm{ml}$ filled volume). The samples were frozen at $-80^{\circ} \mathrm{C}$ in a cold air chamber and then transferred to a pre-cooled shelf at $-50^{\circ} \mathrm{C}$ in a $\mathrm{SMH} 90$ freeze-dryer (Usifroid, Maurepas, France). After a holding step of 1 hour at $-50^{\circ} \mathrm{C}$, the chamber pressure was decreased to $20 \mathrm{~Pa}$ and the shelf temperature was increased to $-20^{\circ} \mathrm{C}$ at $0.25^{\circ} \mathrm{C} / \mathrm{min}$ to initiate the sublimation phase. After 40 hours of sublimation, the shelf temperature was increased to $25^{\circ} \mathrm{C}$ at $0.25{ }^{\circ} \mathrm{C} / \mathrm{min}$ to initiate the desorption phase. After 10 hours of desorption, the vacuum was broken by injection of air and the samples were packed under vacuum in aluminium bags and stored at $-80^{\circ} \mathrm{C}$ until their use for storage experiments. Five fermentations were performed to generate various batches of lyophilized lactic acid bacteria.

\subsection{Storage experiments}


The lyophilized sample of lactic acid bacteria were reduced in powder in a chamber of

106 very low relative humidity (around 5\%) and then put in the containers used for the 107 measurement of water activity. The containers were placed in hermetic glass box containing $108 \mathrm{P}_{2} \mathrm{O}_{5}$ or saturated salt solutions with $\mathrm{a}_{\mathrm{w}}=0.06(\mathrm{LiBr}), \mathrm{a}_{\mathrm{w}}=0.11(\mathrm{LiCl}), \mathrm{a}_{\mathrm{w}}=0.22$ $109\left(\mathrm{CH}_{3} \mathrm{COOK}\right), \mathrm{a}_{\mathrm{w}}=0.32\left(\mathrm{MgCl}_{2} \cdot 6 \mathrm{H}_{2} \mathrm{O}\right), \mathrm{a}_{\mathrm{w}}=0.44\left(\mathrm{~K}_{2} \mathrm{CO}_{3}\right), \mathrm{a}_{\mathrm{w}}=0.53\left(\mathrm{Mg}\left(\mathrm{NO}_{3}\right)_{2} \cdot 6 \mathrm{H}_{2} \mathrm{O}\right), \mathrm{a}_{\mathrm{w}}=$ $1100.75(\mathrm{NaCl}), \mathrm{a}_{\mathrm{w}}=0.84(\mathrm{KCl})$. After one week of equilibration at $25^{\circ} \mathrm{C}$, the samples reached a 111 constant weight and were packed under vacuum in aluminium bags and stored at $25^{\circ} \mathrm{C}$ for 112 different storage times. For each relative humidity condition, three samples were prepared: the

113 first one was used for measuring water activity and water content, the second one for 114 measuring water activity and glass transition temperature and the third one for measuring 115 water activity and biological activity of lactic acid bacteria (viability and acidification 116 activity).

\subsection{Water activity and water content measurements}

The moisture content of the samples was measured by the Karl Fisher titration method using a Metrohom KF 756 apparatus (Herisau, Switzerland). At least $20 \mathrm{mg}$ of powder were mixed with $2 \mathrm{~mL}$ of dry methanol and titrated with Riedel-deHaen reagent (Seelze, Germany) until the end point was reached. The water activity of the samples was measured at $25^{\circ} \mathrm{C}$ using an $\mathrm{a}_{\mathrm{w}}$ meter labMaster-aw (Novasina, Precisa, Poissy, France).

\subsection{Glass transition temperature measurement}

Differential scanning calorimetry (DSC) measurements were performed on two different power compensation DSC equipments (Perkin Elmer LLC, Norwalk, CT, USA) depending on the moisture content of the samples: a Pyris 1 equipped with a mechanical cooling system for the low moisture content samples exhibiting thermal events at the higher temperatures $\left(>0^{\circ} \mathrm{C}\right)$ 
130 and a Diamond equipped with liquid nitrogen cooling accessory (CryoFill) for the high

131 moisture content samples (lower temperatures). Temperature calibration was done using 132 cyclohexane (crystal-crystal transition at $-87.1^{\circ} \mathrm{C}$ ), mercury (melting point at $-38.6^{\circ} \mathrm{C}$ ) and

133 indium (melting point at $156^{\circ} \mathrm{C}$ ) for the Diamond; and cyclohexane (melting point at $6.5^{\circ} \mathrm{C}$ ), 134 n-octodecane (melting point at $27.8^{\circ} \mathrm{C}$ ) and indium for the Pyris 1 . About $10 \mathrm{mg}$ of each 135 sample was placed in $50 \mu$ Perkin Elmer DSC sealed aluminium pans. An empty pan was 136 used as a reference. Linear cooling and heating rates of $10^{\circ} \mathrm{C} \min ^{-1}$ were used. The 137 characteristic glass transition temperature $(\mathrm{Tg})$ of samples was determined as the midpoint 138 temperature of the heat flow step associated with glass transition with respect to the ASTM

139 Standard Method E 1356-91. Results were obtained from at least four replicates.

\subsection{Biological activity measurement}

142 The samples were rehydrated in skim milk to the initial dry matter of the protected 143 bacterial suspension before freeze-drying. Viability of Lactobacillus bulgaricus CFL1 was

144 determined by plate assays on MRS (Biokar Diagnostics, France) agar plates. The Petri dishes 145 were incubated under anaerobic conditions (GENbox96124, BioMérieux, Marcy l'Etoile, 146 France) at $42^{\circ} \mathrm{C}$ for $48 \mathrm{~h}$ before counting.

147 The acidification activity of $100-\mu 1$ samples was measured in milk at $42^{\circ} \mathrm{C}$, in triplicate, 148 using the CINAC System (Corrieu et al., 1988). The time necessary to reach the maximum

149 acidification rate in milk ( $t_{\mathrm{m}}$, in minutes) was used to characterise the acidification activity of 150 the bacterial suspensions. The higher the $t_{m}$, the longer the latency phase and the lower the 151 acidification activity. The acidification activity was measured after equilibration of the 152 samples at various relative humidity conditions and after various time of storage at $25^{\circ} \mathrm{C}$ of 153 the equilibrated samples. 


\section{Results and discussion}

\subsection{Sorption isotherm and glass transition of the lyophilized bacterial matrix}

Figure 1 displays the glass transition temperature $(\mathrm{Tg})$ and the water content of the lyophilized $\mathrm{Lb}$ bulgaricus CFL1 in sucrose matrix as a function of water activity $\left(\mathrm{a}_{\mathrm{w}}\right)$ at $25^{\circ} \mathrm{C}$. The $\mathrm{Tg}$ decreased with water absorption by the matrix. The decrease was linear as water activity increased from 0.1 to 0.7 , which is typical of various amorphous foods (Roos \& Karel, 1991; Roos, 1987). The relationship between water content and water activity was modelled using the well-known equations of Brunauer-Emmet-Tellet (BET) and Guggenheim-Anderson-de Boer (GAB):

$$
\text { GAB equation: } \quad \mathrm{m}=\frac{\mathrm{M}_{\mathrm{M}} \mathrm{C}_{\mathrm{G} / \mathrm{B}} \mathrm{Ka}_{\mathrm{w}}}{\left(1-\mathrm{a}_{\mathrm{w}}\right)\left(1-\mathrm{Ka}_{\mathrm{w}}+\mathrm{C}_{\mathrm{G} / \mathrm{B}} \mathrm{Ka}_{\mathrm{w}}\right)}
$$

Equation 1

Where $\mathrm{m}$ is the water content $\left(\mathrm{g} / \mathrm{g}\right.$ or $\mathrm{g} / 100 \mathrm{~g}$, in dry or wet solid), $\mathrm{M}_{\mathrm{M}}$ is the monolayer water coverage (or the moisture content at fully occupied active sorption sites with one molecule of water), $\mathrm{C}_{\mathrm{G} / \mathrm{B}}$ and $\mathrm{K}$ are adjustable parameters. The BET equation corresponds to the equation 1 with the parameter $\mathrm{K}$ equal to 1.

By using the sorption isotherm, it is possible to calculate the water content value for each experimental value of glass transition temperature. The Gordon and Taylor's equation was used to model data on Tg of the lyophilized bacterial matrix:

$$
\mathrm{T}_{\mathrm{gm}}=\frac{\mathrm{X}_{\mathrm{w}} \mathrm{T}_{\mathrm{gw}}+\mathrm{k}_{\mathrm{GT}}\left(1-\mathrm{X}_{\mathrm{w}}\right) \mathrm{T}_{\mathrm{gs}}}{\mathrm{X}_{\mathrm{w}}+\mathrm{k}_{\mathrm{GT}}\left(1-\mathrm{X}_{\mathrm{w}}\right)}
$$

Where $\mathrm{Tg}_{\mathrm{m}}, \mathrm{Tg}_{\mathrm{s}}$, and $\mathrm{Tg}_{\mathrm{w}}$, are the glass transition temperatures $(\mathrm{K})$ of the mixture, of the solids and the water, respectively, $\mathrm{X}_{\mathrm{w}}$ is the mass fraction of water, and $\mathrm{k}_{\mathrm{GT}}$ is a constant. The glass transition temperature of pure water was taken as $\mathrm{Tg}_{\mathrm{w}}=-135^{\circ} \mathrm{C}$.

The resulting parameters of the GAB, BET and Gordon and Taylor equations are reported in Table 1. The table was completed with data from literature works on bacteria, proteins and sugars. 
Using the relationships between water activity, water content and glass transition temperature, the physical storage stability of the lyophilized product can be predicted.

181 Referring to the critical $\mathrm{Tg}$ of $25^{\circ} \mathrm{C}$, corresponding to storage at ambient temperature, the colyophilized matrix of Lb bulgaricus CFL1 and sucrose showed a critical value of water activity of 0.241 corresponding to a critical value of water content of $3.9 \%$. This critical $a_{w}$

184 value is in accordance with previous work reported on LAB freeze-dried in sugar matrix 185 (around 0.25 ) and slightly higher that the critical $\mathrm{a}_{\mathrm{w}}$ value of pure sucrose $(0.235)$. This small effect of bacteria was previously observed by (Fonseca et al., 2001). The low value observed for the matrix $\mathrm{LAB}+$ sucrose $+\mathrm{Md} 12(0.145)$ may be ascribed to the presence of maltodextrin resulting in changes in sorption properties.

189 The parameters, $\mathrm{M}_{\mathrm{M}}$ and $\mathrm{C}_{\mathrm{B}}$, of the BET equation have both physical significance: the 190 amount of water needed to achieve monolayer coverage and the energy term related to overall energy of absorption, respectively. For Lb bulgaricus CFL1 co-lyophilized with sucrose or

192 fermented medium composed of various sugars, $M_{M}$ tended to be lower than that expected 193 value based on contributions of the pure bacteria and protective medium. This deviation 194 suggests that the interaction of amorphous sugars and bacteria in the solid state reduces the 195 availability of water-binding sites. The $\mathrm{M}_{\mathrm{M}}$ value, lower than expected, may also be 196 considered as evidence of the water replacement mechanism proposed for preservation of 197 dehydrated biological systems: i.e. hydrogen bonding between the sugar and the 198 biomolecules, especially the membrane proteins, when water is removed during drying 199 (Carpenter \& Crowe, 1989; Costantino et al., 1998; Crowe et al., 1988; Prestrelski et al., 200 1993). Furthermore, a number of physicochemical properties change at the monolayer water 201 coverage: heat capacity, protein conformational state, etc (Lechuga-Ballesteros et al., 2002). 202 The mobility of water is restricted below $\mathrm{M}_{\mathrm{M}}$ and water molecules are tightly bound to others 203 molecules (proteins, polymers, small solutes) at such hydration levels (Lechuga-Ballesteros et 
al., 2002). It has been suggested that the onset of internal protein flexibility correlated well with the attainment of monolayer coverage of water (Hageman, 1992). Thus freeze-dried proteins might exhibit increased instability above the monolayer coverage, and therefore BET monolayer water coverage appears as a useful physical property for protein formulation development (Costantino et al., 1997, 1998). Some other studies have suggested that the optimal water content for stability corresponds to the water content needed for monolayer coverage of the available surface (Hsu et al., 1992; Karel \& Labuza, 1967). Concerning lactic acid bacteria, it seems interesting to verify if the relationship between $M_{M}$ and the optimal water content is the same as for proteins.

\subsection{Effect of water activity on the acidification activity of freeze-dried bacteria}

Figure 2 displays the evolution of the acidification activity characterized by the parameter $t_{m}$ as a function of the water activity of the freeze-dried bacterial suspension just after $\mathrm{a}_{\mathrm{w}}$ equilibration of the samples, and after 7,10 and 29 days of storage at $25^{\circ} \mathrm{C}$. The lower the $t_{m}$ value, the higher the acidification activity. An inversed bell-shape curve was observed with a minimal $t_{\mathrm{m}}$ value, and thus a maximal acidification activity around a value of water activity of 0.2 whatever the storage time. As expected, the $t_{m}$ value increased with the storage time and that increase appeared more pronounced for the high values of water activity. The degradation of the acidification activity can be ascribed to the cell death and/or to cell membrane damages leading to higher latency phase. In order to combine the viability and the acidification activity, the specific acidification activity $\left(\mathrm{t}_{\text {spe, }}\right.$, in $\left.\mathrm{min} / \log (\mathrm{CFU} / \mathrm{ml})\right)$ was defined as the ratio of $t_{m}$ to the corresponding log of cell concentration (Streit et al., 2007). Figure 3 showed the evolution of the specific acidification activity $\left(\mathrm{t}_{\mathrm{spe}}\right)$ with the storage time for three relative humidity conditions. Whatever the water activity of the samples, the parameter $t_{\text {spe }}$

228 increased linearly with storage time according to the following relationship: 


$$
\mathrm{t}_{\mathrm{spe}}=\mathrm{k}_{\mathrm{spe}} \times \text { Storage time }+\mathrm{A} \quad \text { Equation } 3
$$

Where $\mathrm{k}_{\mathrm{spe}}$ is the slope of the regression line $\left(\mathrm{in}(\mathrm{min} /(\log (\mathrm{CFU} / \mathrm{ml}))) /\right.$ day or $\mathrm{t}_{\mathrm{spe}} /$ day $)$

231 and represents the rate of loss in specific acidification activity during storage. A higher slope 232 indicated a faster decrease of the specific acidification activity and, consequently a lower 233 resistance to storage under various relative humidity conditions. Previous works have already 234 described the acidification activity loss with storage time as a linear relationship for frozen 235 lactic acid concentrates (Fonseca et al., 2000; Streit et al., 2007). The rate constants of loss of specific acidification activity $\mathrm{k}_{\mathrm{spe}}$ at storage temperature of $25^{\circ} \mathrm{C}$ are plotted as function of water activity in Figure 4. The water activity threshold between glassy and rubbery states as well as the values of the temperature difference between the storage temperature and the glass 239 transition temperature $\left(\mathrm{T}_{\text {storage }}-\mathrm{Tg}\right)$ are shown. Storage of the co-lyophilized matrix of $L b$ 240 bulgaricus CFL1 and sucrose below Tg, where the molecular mobility is sharply reduced due to the very viscosity of the amorphous state, resulted in very low rates of loss of specific 242 acidification activity, lower than $2 t_{\text {spe }} /$ day. The specific acidification activity loss rate did not 243 sharply increase with increasing water activity, as would be expected given the plasticizing 244 effect of water on $\mathrm{Tg}$ and thus on mobility. The acceleration of the degradation reactions 245 starts at water activity higher than 0.33 and $\mathrm{T}_{\text {storage }}-\mathrm{Tg}$ higher than $10^{\circ} \mathrm{C}$. Furthermore, for water activity around $0.5-0.6$, the degradation rate tends to decrease. This unpredicted event 247 can be ascribed to a physical change in the matrix, probably related to the sugar 248 crystallization. After this event, the rate of loss of specific acidification activity sharply 249 increases, probably due to the H- bonding breakage between the protecting sugar and cell 250 biomolecules (like membrane proteins and phospholipids). Many works have related the glass transition to the kinetics of diffusion-controlled 252 chemical reaction such as Maillard reaction or nonenzymatic browning (NEB), a very 253 important chemical reaction in foods (Bhandari \& Howes, 1999; Buera \& Karel, 1995; 
254 Karmas et al., 1992; Lievonen et al., 2002; Roos \& Himberg, 1994; Schebor et al., 1999).

255 Even if a non reducing sugar (sucrose) was used in the protective medium added to the $L b$ 256 bulgaricus CFL1 suspension before freeze-drying, some browning of the powder was 257 observed for the $a_{w}$ values higher than 0.5 . That browning could be ascribed to the residual 258 fermented medium containing reducing sugars (lactose, glucose, galactose) in the 259 concentrated bacterial suspension and/or to the hydrolysis of sucrose in acidic conditions. 260 Several authors have investigated the Maillard reaction rate in milk powders or dehydrated 261 model systems and have shown relationships between the reaction rates and the physical state 262 of the amorphous matrix (Buera \& Karel, 1995; Karmas et al., 1992; Pereyra Gonzales et al., 263 2010; Schebor et al., 1999). A large increase in the nonenzymatic browning rate was reported 264 at a range of $2^{\circ} \mathrm{C}$ to $40^{\circ} \mathrm{C}$ above $\mathrm{Tg}$ (Karmas et al., 1992; Lievonen et al., 1998; Pereyra 265 Gonzales et al., 2010; Roos et al., 1996). Water plasticization increases molecular mobility, 266 which may also result in the conversion of sugars such as sucrose and lactose from the 267 amorphous state to the crystalline state (Roos \& Karel, 1992). In closed systems, 268 disaccharides crystallization will induce an increase in $\mathrm{a}_{\mathrm{w}}$ due to the release of water from 269 amorphous sugar, thus accelerating deteriorative changes such as NEB (Jouppila \& Roos, 270 1994a; Vuataz, 2002). Above glass transition temperature, the nonenzymatic browning rate in 271 model systems appeared to be influenced by the temperature difference (T-Tg) (Buera \& 272 Karel, 1995). Furthermore, nonenzymatic browning has been showed to proceed at the slow 273 rate even well below the glass transition temperature (Karmas et al., 1992; Lievonen et al., 274 1998; Roos \& Himberg, 1994; Schebor et al., 1999), which could explain the small losses of 275 specific acidification activity observed at low moisture content $(\mathrm{T}<\mathrm{Tg})$. The inactivation of freeze-dried lactic acid bacteria during storage almost certainly 277 resulted not only from the nonenzymatic browning but also from other complex chemical 278 reactions such as oxidation, protein denaturation etc (Kurtmann et al., 2009a; Lai \& Topp, 
1999; Teixeira et al., 1996). The mechanism of diffusion limited chemical reaction associated

280 to the glassy state does not allows to wholly explain the complex bacteria inactivation 281 behavior. The various works on freeze-dried lactic acid bacteria revealed that the bacteria 282 inactivation rate increased with water content and that storage of the samples in the glassy 283 state led to a better survival of bacteria(Higl et al., 2007; Kurtmann et al., 2009b; Pehkonen et 284 al., 2008; Schoug et al., 2010; Selma et al., 2007). However, there is no common acceptance 285 to identify the glass transition temperature as a stability threshold. Some authors reported the acceleration of the degradation rate for temperature lower than $\mathrm{Tg}$ and others authors for temperature well above the Tg. Furthermore, the inactivation rate appears to depend on the strain of the lactic acid bacteria and on the composition of the protective medium. For instance, the inactivation rate of bacteria freeze-dried in a lactose matrix was reported higher than the inactivation rate of bacteria freeze-dried in a sucrose matrix (Kurtmann et al., 2009b). Among the various works investigating the stability of freeze-dried lactic acid bacteria (Higl et al., 2007; Kurtmann et al., 2009b; Pehkonen et al., 2008; Schoug et al., 2010; Selma et al., 2007; Zayed \& Roos, 2004), very few have focused on the study of the inactivation rate

294 at low moisture content and below Tg. Figure 5 displays the relationships between water 295 activity, water content, glass transition temperature and the rate of specific acidification activity loss. Additional sets of experimental data on bacteria stability have been included.

297 The three batches of freeze-dried bacteria differed in the physiological state of the bacteria 298 obtained after the fermentation process. The values of $a_{w}$ corresponding to the monolayer 299 water coverage $\left(\mathrm{M}_{\mathrm{M}}\right)$ and to the threshold between glassy and rubbery states $\left(\mathrm{T}_{\text {storage }}-\mathrm{Tg}=0\right)$ 300 are reported in the figure. Whatever the batch, very low rates of loss of specific acidification 301 activity were observed for water activities lower than the $a_{w}$ value corresponding the 302 monolayer water coverage $\mathrm{M}_{M}\left(\mathrm{a}_{\mathrm{w}}=0.214\right)$ and the rates tended to increase for $\mathrm{a}_{\mathrm{w}}$ value 303 lower than 0.1 . The optimal range of water activity and water content for Lb bulgaricus CFL1 
304 freeze-dried in sucrose matrix appears to be $0.1-0.241$ and $2.5-3.7 \%$, respectively. For

305 values of $\mathrm{a}_{\mathrm{w}}$ comprised between 0.214 (corresponding to $\mathrm{M}_{\mathrm{M}}$ ) and 0.241 (corresponding to $306 \mathrm{~T}_{\text {storage }} \mathrm{Tg}=0^{\circ} \mathrm{C}$ ), the rate of loss of specific acidification activity slightly increased. And the 307 increase of loss rate became more pronounced for $\mathrm{a}_{\mathrm{w}}$ values higher than 0.241 . The mobility 308 of water is restricted below $\mathrm{M}_{\mathrm{M}}$ since water molecules are tightly bound to biomolecules 309 surface at such hydration levels. Moreover, at constant temperature, the water mobility above $310 \mathrm{M}_{\mathrm{M}}$ and below the amount of water required to depress $\mathrm{Tg}$ to the storage temperature is 311 increased, but remains lower than the mobility in rubbery state.

313 for freeze-dried biological product such as protein, viruses, gene vectors, DNA lipoplex

314 formulation and lactic acid bacteria (Lb bulgaricus, Lb rhamnosus and Lb salivarius) are rare 315 but do exist (Breen et al., 2001; Chang et al., 2005b; Croyle et al., 2001; Greiff, 1970; Hsu et 316 al., 1992; Pehkonen et al., 2008; Pikal et al., 1992; Scott, 1958; Teixeira et al., 1995; Yu \& 317 Anchordoquy, 2009; Zayed \& Roos, 2004). Teixeira et al., 1995 also reported greatest 318 survival rate for $\mathrm{Lb}$ bulgaricus spray dried with skim milk stored at $4^{\circ} \mathrm{C}$ and $20^{\circ} \mathrm{C}$ for $\mathrm{a}_{\mathrm{w}}$ 319 values of 0.11 and 0.23 , respectively. According to Chang et al., 2005a, optimal stability at 320 intermediate water content appears to support the water substitute mechanism for protein 321 stabilization. That is, the water substitute concept states that the hydrogen bonding between 322 water and protein is critical to the thermodynamic stability of protein. At low to intermediate 323 water level, the water may be binding to the hydrogen-bonding sites on the surface of protein 324 which have not been occupied by the sugars. Therefore the stability can be improved with the 325 addition of small amount of water. Furthermore, no antioxidant was added to the $L b$ 326 bulgaricus CFL1 concentrated suspension before freeze-drying. In very dry formulations, 327 different oxidation pathways appear to dominate protein and lipid degradation (Yu \& 328 Anchordoquy, 2009). The rate of oxidation is observed to have a minimum at the monolayer 
hydration level, and to increase at lower and higher water contents (Labuza, 1980; Lai \&

330 Topp, 1999; Pikal et al., 1991). This antioxidant effect of water has been ascribed to its

331 interaction with functional groups, which blocks these reaction sites, thereby preventing them

332 from interacting with oxygen (Lechuga-Ballesteros et al., 2002). The losses of specific

333 acidification activity observed at low $\mathrm{a}_{\mathrm{w}}$ values may then be ascribed to oxidative membrane

334 mechanisms (Kurtmann et al., 2009a; Teixeira et al., 1996).

\section{Conclusion:}

The stability of lactic acid bacteria in a glass or rubbery sucrose matrix at different water activity environments was analyzed. The physical properties of the matrix were determined by means of state diagram and sorption isotherm. The Brunauer-Emmett-Teller

340 (BET) equation was used to describe the sorption properties and to determine the monolayer water coverage $\mathrm{M}_{\mathrm{M}}$, reported as the optimal value of water content for product stability. When

342 plotting the loss rate of specific acidification activity of Lb bulgaricus CFL1 as a function of 343 water activity and positioning the $a_{w}$ values corresponding to the $M_{M}$ parameter $\left(a_{w}\left(M_{M}\right)\right)$ and

344 to $\mathrm{T}_{\text {storage }}-\mathrm{Tg}=0^{\circ} \mathrm{C}\left(\mathrm{a}_{\mathrm{w}}(\mathrm{Tg})\right)$, the $\mathrm{a}_{\mathrm{w}}\left(\mathrm{M}_{\mathrm{M}}\right)$ appears as a threshold value for bacteria stability.

345 Above $\mathrm{a}_{\mathrm{w}}\left(\mathrm{M}_{\mathrm{M}}\right)$, the degradation rate slightly increased and this increased was more 346 pronounced above $\mathrm{a}_{\mathrm{w}}(\mathrm{Tg})$, attributable to the physical changes of the matrix. Furthermore, a

347 slight increase of the degradation rate was also observed for very low value of $\mathrm{a}_{\mathrm{w}}(<0.1)$, 348 probably caused by oxidative mechanisms and slow but still present Maillard reaction.

349 Our experimental results and especially the very low value of $\mathrm{M}_{\mathrm{M}}$ compared to the 350 value of the pure sugar provide some evidences of a protective mechanism of sucrose: direct 351 interaction with the bacteria by establishing hydrogen bonding with the membrane proteins 352 and/or the lipid bilayer. Further studies are in progress to verify this mechanism and also to 353 generalize this approach with other protective medium including polymers or 
354 polysaccharides. The concept of monolayer water coverage provides an interesting framework 355 for describing effects of water on the stability of glassy solids and is useful in the 356 development of freeze-dried biological products. Overdrying may be detrimental to the

357 stability of bacteria in the dried state, even when formulated with disaccharides. Combining 358 the relationships between water activity and glass transition temperature, water content and 359 biological activity appeared as a promising approach allowing a rational optimization of the 360 freeze drying process and the prediction of storage stability of lactic acid bacteria.

\section{5. Acknowledgements}

363 The research leading to these results has received funding from the European 364 Community's Seventh Framework Programme (FP7/2007-2013) under grant agreement CAFÉ $365 \mathrm{n}^{\circ}$ KBBE-212754 (CAFÉ Project: Computer-Aided Food processes for control Engineering). 


\section{References}

369 Abadias, M., Benabarre, A., Teixido, N., Usall, J., \& Vinas, I. (2001). Effect of freeze drying and protectants on viability of the biocontrol yeast Candida sake. International Journal of Food Microbiology, 65, 3, 173-182.

Bhandari, B. R., \& Howes, T. (1999). Implication of glass transition for the drying and stability of dried foods. Journal of Food Engineering, 40, 71-79.

374 Breen, A. D., Curley, J. G., Overcashier, D. E., Hsu, C. C., \& Shire, S. J. (2001). Effect of moisture on the stability of a lyophilized humanized monoclonal antibody formulation. Pharmaceutical Research, 18, 9, 1345-1353.

Buera, M. P., \& Karel, M. (1995). Effect of physical changes on the rates of nonenzymic 378 browning and related reactions. Food Chemistry, 52, 167-173.

379 Buera, P., Schebor, C., \& Elizalde, B. (2005). Effects of carbohydrate crystallization on stability of dehydrated foods and ingredient formulations. Journal of Food Engineering, 67, $1-2,157-165$.

Carpenter, J. F., \& Crowe, J. H. (1989). An infrared spectroscopic study of the interactions of 383 carbohydrates with dried proteins. Biochemistry, 28, 9, 3916-3922.

384 Carvalho, A. S., Silva, J., Ho, P., Teixeira, P., Malcata, F. X., \& Gibbs, P. (2004). Relevant 385 factors for the preparation of freeze-dried lactic acid bacteria. International Dairy Journal, 14, $386 \quad 10,835-847$.

387 Castro, H. P., Teixeira, P. M., \& Kirby, R. (1997). Evidence of membrane damage in 388 Lactobacillus bulgaricus following freeze-drying. Journal of Applied Microbiology, 82, 8738994.

390 Champagne, C. P., Gardner, N., Brochu, E., \& Beaulieu, Y. (1991). The freeze-drying of 391 lactic acid bacteria. A review. Canadian Institute of Food Science and Technology, 24, 118392128. 
Chang, L. Q., Shepherd, D., Sun, J., Ouellette, D., Grant, K. L., Tang, X. L., et al. (2005a).

394 Mechanism of protein stabilization by sugars during freeze-drying and storage: Native structure preservation, specific interaction, and/or immobilization in a glassy matrix? Journal of Pharmaceutical Sciences, 94, 7, 1427-1444.

Chang, L. Q., Shepherd, D., Sun, J., Tang, X. L., \& Pikal, M. J. (2005b). Effect of sorbitol 398 and residual moisture on the stability of lyophilized antibodies: Implications for the 399 mechanism of protein stabilization in the solid state. Journal of Pharmaceutical Sciences, 94, 7, 1445-1455.

401

Conrad, P. B., Miller, D. P., Cielenski, P. R., \& de Pablo, J. J. (2000). Stabilization and 402 preservation of Lactobacillus acidophilus in saccharide matrices. Cryobiology, 41, 1, 17-24.

403 Corrieu, G., Spinnler, H. E., Picque, D., \& Jomier, Y. (1988). Automated system to follow up 404 and control the acidification activity of lactic acid starters. France: Institut National de la 405 Recherche Agronomique.

406 Costantino, H. R., Curley, J. G., \& Hsu, C. C. (1997). Determining the water sorption 407 monolayer of lyophilized pharmaceutical proteins. Journal of Pharmaceutical Sciences, 86, $408 \quad 12,1390-1393$.

409 Costantino, H. R., Curley, J. G., Wu, S., \& Hsu, C. C. (1998). Water sorption behavior of 410 lyophilized protein-sugar systems and implications for solid-state interactions. International 411 Journal of Pharmaceutics, 166, 2, 211-221.

412 Crowe, J. H., Carpenter, J. F., \& Crowe, L. M. (1998). The role of vitrification in 413 anhydrobiosis. Annual Review of Physiology, 60, 73-103.

414 Crowe, J. H., Crowe, L. M., Carpenter, J. F., Rudolph, A. S., Wistrom, C. A., Spargo, B. J., et 415 al. (1988). Interactions of sugars with membranes. Biochimica et Biophysica Acta, 947, 367416384. 
417 Crowe, J. H., Ried, D. S., \& Crowe, L. M. (1996). Is trehalose special for preserving dry 418 biomaterials? Biophysical Journal, 71, 2087-2093.

419 Croyle, M., Cheng, X., \& Wilson, J. (2001). Development of formulations that enhance 420 physical stability of viral vectors for gene therapy. Gene Therapy, 8, 1281-1290.

421 Fonseca, F., Beal, C., \& Corrieu, G. (2000). Method of quantifying the loss of acidification 422 activity of lactic acid starters during freezing and frozen storage. Journal of Dairy Research, $42367,83-90$.

424 Fonseca, F., Obert, J. P., Béal, C., \& Marin, M. (2001). State diagrams and sorption isotherms 425 of bacterial suspensions and fermented medium. Thermochimica Acta, 366, 167-182.

426 Greiff, D. (1970). Stabilities of suspensions of influenza virus dried by sublimation of ice in 427 vacuo to different contents of residual moisture and sealed under different gases. Applied 428 Microbiology, 20, 935-938.

429 Hageman, M. J. (1992). Water sorption and solid-state stability of proteins. In T. J. Ahern \& 430 M. C. Manning (Eds.), Stability of protein pharmaceutics. Part A. Chemical and physical 431 pathways of protein degradation (pp. 273-309). New York: Plenum.

432 Higl, B., Kurtmann, L., Carlsen, C. U., Ratjen, J., \& Först, P. (2007). Impact of water activity 433 and physical state on the storage stability of Lactobacillus paracasei ssp paracasei freeze434 dried in a lactose matrix. Biotechnology Progress, 23, 4, 794-800.

435 Hsu, C. C., Ward, C. A., Pearlman, R., Nguyen, H. M., Yeung, D. A., \& Curley, J. G. (1992). 436 Determining the optimum residual moisture in lyophilizes protein pharmaceuticals. 437 Development in Biologicals Standardization, 74, 255-271.

438 Jouppila, K., \& Roos, Y. H. (1994a). Glass transitions and crystallization in milk powders. 439 Journal of Dairy Science, 77, 2907-2915.

440 Jouppila, K., \& Roos, Y. H. (1994b). Water sorption and time-dependent phenomena of milk 441 powders. Journal of Dairy Science, 77, 1798-1808. 
442 Karel, M., \& Labuza, T. P. (1967). Chemical changes in freeze-dried foods and models 443 systems. Cryobiology, 3, 288-296.

444 Karmas, R., Buera, M. P., \& Karel, M. (1992). Effect of glass transition on rates of 445 nonenzymatic browning in food systems. Journal of Agricultural and Food Chemistry, 40, $446 \quad 873-879$.

447 Kurtmann, L., Carlsen, C. U., Risbo, J., \& Skibsted, L. H. (2009a). Storage stability of freeze448 dried Lactobacillus acidophilus (La-5) in relation to water activity and presence of oxygen 449 and ascorbate. Cryobiology, 58, 175-180.

450 Kurtmann, L., Carlsen, C. U., Skibsted, L. H., \& Risbo, J. (2009b). Water activity451 temperature state diagram of freeze-dried Lactobacillus acidophilus (La-5): Influence of 452 physical state on bacterial survival during storage. Biotechnology Progress, 25, 1, 265-270.

453 Labuza, T. (1980). The effect of water activity on reaction kinetics of food deterioration. 454 Food Technology, 34, 4, 36-41, 59.

455 Lai, M. C., \& Topp, E. M. (1999). Solid-state chemical stability of proteins and peptides. 456 Journal of Pharmaceutical Sciences, 88, 5, 489-500.

457 Lechuga-Ballesteros, D., Miller, D. P., \& Zhang, J. (2002). Residual water in amorphous 458 solids: Measurements and effects on stability. In H. Levine (Ed.), Progress in Amorphous 459 Food and Pharmaceutical Systems. London: The Royal Sociéty of Chemistry.

460 Leslie, S. B., Israeli, E., Lighthart, B., Crowe, J. H., \& Crowe, L. M. (1995). Trehalose and 461 sucrose protect both membranes and proteins in intact bacteria during drying. Applied and 462 Environmental Microbiology, 61, 10, 3592-3597.

463 Lievonen, S. M., Laaksonen, T. J., \& Roos, Y. H. (1998). Glass transition and reaction rates: 464 nonenzymatic browning in glassy and liquid systems. Journal of Agricultural and Food 465 Chemistry, 46, 2778-2784. 
Lievonen, S. M., Laaksonen, T. J., \& Roos, Y. H. (2002). Nonenzymatic Browning in Food 467 Models in the Vicinity of the Glass Transition: Effects of Fructose, Glucose, and Xylose as Reducing Sugar. Journal of Agricultural and Food Chemistry, 50, 24, 7034-7041.

The challenges of drying probiotic cultures. Food Chemistry, 106, 4, 1406-1416.

Miao, S., Mills, S., Stanton, C., Fitzgerald, G. F., Roos, Y. H., \& Ross, R. P. (2008). Effect of 472 disaccharides on survival during storage of freeze-dried probiotics. Dairy Science and Technology, 88, 19-30.

Naidu, A. S., Bidlack, W. R., \& Clemens, R. A. (1999). Probiotic spectra of lactic acid bacteria (LAB). Critical Reviews in Food Science and Nutrition, 39, 13-126.

476 Patist, A., \& Zoerb, H. (2005). Preservation mechanisms of trehalose in food and biosystems. 477 Colloids and Surfaces B: Biointerfaces, 40, 2, 107-113.

478 Pehkonen, K. S., Roos, Y. H., Miao, R. P., Ross, R. P., \& Stanton, C. (2008). State transitions 479 and physicochemical aspects of cryoprotection and stabilization in freeze-drying of 480 Lactobacillus rhamnosus GG (LGG). Journal of Applied Microbiology, 104, 1732-1743.

481 Pereyra Gonzales, A. S., Naranjo, G. B., Leiva, G. E., \& Malec, L. S. (2010). Maillard 482 reaction kinetics in milk powder: Effect of water activity at mild temperatures. International 483 Dairy Journal, 20, 40-45.

Pikal, M. J. (1999). Mechanisms of protein stabilization during freeze-drying and storage : The relative importance of thermodynamic stabilization and glassy state relaxation dynamics. In L. Rey \& J. C. May (Eds.), Freeze-drying / Lyophilisation of pharmaceutical and 487 biological products (Vol. 96, pp. 161-198). NeW York: Marcel Dekker.

488 Pikal, M. J., Dellerman, K., \& Roy, M. L. (1992). Formulation and stability of freeze-dried 489 proteins: Effects of moisture and oxygen on the stability of freeze-dried formulations of 490 human growth hormone. Development in Biologicals Standardization, 74, 21-38. 
491 Pikal, M. J., Dellerman, K. M., Roy, M. L., \& Riggin, R. M. (1991). The effects of 492 formulation variables on the stability of freeze-dried human growth hormone. Pharmaceutical 493 Research, 8, 4, 427-436.

494 Prestrelski, S. J., Tedeschi, N., Arakawa, T., \& Carpenter, J. F. (1993). Dehydration-induced 495 conformational transitions in proteins and their inhibition by stabilizers. Biophysical Journal, $496 \quad 65,2,661-671$.

497 Roos, Y. (1995). Characterization of food polymers using state diagrams. Journal of Food 498 Engineering, 24, 339-360.

499 Roos, Y., Jouppila, K., \& Zielasko, B. (1996). Non-enzymatic browning-induced water 500 plasticization. Glass transition temperature depression and reaction kinetics determination 501 using DSC. Journal of Thermal Analysis, 47, 1437-1450.

502 Roos, Y., \& Karel, M. (1991). Phase transitions of mixtures of amorphous polysaccharides 503 and sugars. Biotechnology Progress, 7, 1, 49-53.

504 Roos, Y., \& Karel, M. (1992). Crystallization of amorphous lactose. Journal of Food Science, $505 \quad 57,775-777$.

506 Roos, Y. H. (1987). Effect of moisture on the thermal behavior of strawberries studied using 507 differential scanning calorimetry. Journal of Food Science, 52, 146-149.

508 Roos, Y. H. (1993). Water activity and physical state effects on amorphous food stability. 509 Journal of Food Processing and Preservation, 16, 6, 433-447.

510 Roos, Y. H. (1997). Frozen state transitions in relation to freeze drying. Journal of Thermal 511 analysis, 48, 535-544.

512 Roos, Y. H. (2002). Importance of glass transition and water activity to spray drying and 513 stability of dairy powders. Lait, 82, 4, 475-484. 
514 Roos, Y. H., \& Himberg, M. J. (1994). Nonenzymatic browning behavior, as related to glass 515 transition, of a food model at chilling temperatures. Journal of Agricultural and Food 516 Chemistry, 42, 893-898.

517 Santivarangkna, C., Higl, B., \& Foerst, P. (2008). Protection mechanisms of sugars during 518 different stages of preparation process of dried lactic acid starter cultures. Food Microbiology $51925,429-441$

520 Schebor, C., Buera, M. P., Karel, M., \& Chirife, J. (1999). Color formation due to non521 enzymatic browning in amorphous, glassy, anhydrous, model systems. Food Chemistry 65 (1999) $427 \pm 432,65,427-432$.

Schoug, A., Mahlin, D., Jonson, M., \& Hakansson, S. (2010). Differential effects of polymers 524 PVP90 and Ficoll400 on storage stability and viability of Lactobacillus coryniformis Si3 freeze-dried in sucrose. Journal of Applied Microbiology, 108, 1032-1040. Scott, W. J. (1958). The effect of residual water on the survival of dried bacteria during storage. Journal of General Microbiology, 19, 624-633.

528 Selma, M. V., MacNaughtan, W., Mitchell, J., \& Waites, W. (2007). Optimisation of 529 production and storage stability of the starter bacteria Streptococcus thermophilus and 530 Lactobacillus plantarum. Journal of the Science of Food and Agriculture, 87, 5, 765-772.

531 Slade, L., \& Levine, H. (1991). Beyong water activity: recent advances based on an 532 alternative approach to the assessment of food quality and food safety. Critical Review in 533 Food Science and Nutrition, 30, 115-360.

534 Streit, F., Corrieu, G., \& Beal, C. (2007). Acidification improves cryotolerance of 535 Lactobacillus delbrueckii subsp. bulgaricus CFL1. Journal of Biotechnology, 128, 659-667.

536 Sun, W. Q., \& Davidson, P. (1998). Protein inactivation in amorphous sucrose and trehalose 537 matrices : Effects of phase separation and crystallization. Biochimica et Biophysica Acta, $1425,235-244$. 
539 Teixeira, P., Castro, H., \& Kirby, R. (1996). Evidence of membrane lipid oxidation of spray-

540 dried Lactobacillus bulgaricus during storage. Letters in Applied Microbiology, 22, 34-38.

541 Teixeira, P. C., Castro, M. H., Malcata, F. X., \& Kirby, R. M. (1995). Survival of

542 Lactobacillus delbrueckii ss bulgaricus following spray-drying. Journal of Dairy Science, 78,

$5435,1025-1031$.

544 Teng, C. D., Zarrintan, M. H., \& Groves, M. J. (1991). Water vapor adsorption and desorption

545 isotherms of biologically active proteins. Pharmaceutical Research, 8, 2, 191-195.

546 Vuataz, G. (2002). The phase diagram of milk: a new tool for optimising. Lait, 82, 485-500.

547 Yu, J. X., \& Anchordoquy, T. J. (2009). Effects of Moisture Content on the Storage Stability

548 of Dried Lipoplex Formulations. Journal of Pharmaceutical Sciences, 98, 9, 3278-3289.

549 Zayed, G., \& Roos, Y. H. (2004). Influence of trehalose and moisture content on survival of

550 Lactobacillus salivarius subjected to freeze-drying and storage. Process Biochemistry, 39, 9, $551 \quad 1081-1086$.

552 Zhang, J., \& Zografi, G. (2000). The relationship between "BET" and "free volume"-derived 553 parameters for water vapor absorption into amorphous solids. Journal of Pharmaceutical 554 Sciences, 89, 8, 1063-1072.

555 Zhao, G., \& Zhang, G. (2005). Effect of protective agents, freezing temperature, rehydration 556 media on viability of malolactic bacteria subjected to freeze-drying. Journal of Applied 557 Microbiology, 99, 2, 333-338. 


\section{Table captions}

563

564 Table 1. Estimated values of the parameters of the BET, GAB and Gordon and Taylor 565 equations for the concentrated suspension Lactobacillus bulgaricus CFL1 lyophilized in a 566 sucrose matrix and for selected bacterial suspensions and pure solutes.

567

568

569 


\section{Figure Captions}

572 Fig. 1. Relationships between glass transition temperature $(\mathrm{Tg})$, water activity $\left(\mathrm{a}_{\mathrm{w}}\right)$ and water content $(\mathrm{m})$ for bacterial suspension freeze-dried in a sucrose matrix. Lines indicate the 574 location of critical $\mathrm{Tg}$, aw and $\mathrm{m}$ values at $25^{\circ} \mathrm{C}$.

Fig. 2. Acidification activity (tm) of lyophilized Lactobacillus bulgaricus CFL1 in a sucrose matrix as a function of water activity for different storage times (ts) at $25^{\circ} \mathrm{C}$.

Fig. 3. Specific acidification activity $\left(\mathrm{t}_{\text {spe }}\right)$ of lyophilized Lactobacillus bulgaricus CFL1 in a sucrose matrix as a function of storage time (ts) at $25^{\circ} \mathrm{C}$ for different values of water activity $(0.177 ; 0.326 ; 0.551) . \mathrm{k}_{\text {spe }}:$ rate of loss of specific acidification activity during storage at $25^{\circ} \mathrm{C}$ $((\min /(\log (\mathrm{CFU} / \mathrm{ml}))) /$ day $) ; \mathrm{t}_{\text {spe }}=0.2 \mathrm{x}$ ts $+40.7\left(\mathrm{a}_{\mathrm{w}}=0.177\right) ; \mathrm{t}_{\mathrm{spe}}=1.5 \times$ ts $+46.4\left(\mathrm{a}_{\mathrm{w}}=\right.$ $0.326) ; \mathrm{t}_{\mathrm{spe}}=8.1 \times$ ts $+77\left(\mathrm{a}_{\mathrm{w}}=0.551\right)$.

Fig.4. Rate of loss of specific acidification activity during storage at $25^{\circ} \mathrm{C}$ of lyophilized Lactobacillus bulgaricus CFL1 in a sucrose matrix $\left(\mathrm{k}_{\mathrm{spe}}\right.$, in $(\mathrm{min} /(\log (\mathrm{CFU} / \mathrm{ml}))) /$ day $)$ as a function of water activity $\left(a_{w}\right)$. A vertical line indicates the threshold value of $a_{w}$ between the glassy and the rubbery states. In bold under the $\mathrm{x}$ axis, are reported the values of the temperature difference $\mathrm{T}-\mathrm{Tg}$, (with $\mathrm{T}=25^{\circ} \mathrm{C}$ ) corresponding to the $\mathrm{a}_{\mathrm{w}}$ values.

591 Fig. 5. Relationships between rate of loss of specific acidification activity during storage at $59225^{\circ} \mathrm{C}\left(\mathrm{k}_{\text {spe }}\right.$, in $(\mathrm{min} /(\log (\mathrm{CFU} / \mathrm{ml}))) /$ day $)$, glass transition temperature $(\mathrm{Tg})$, water activity $\left(\mathrm{a}_{\mathrm{w}}\right)$ and water content (m) for bacterial suspension freeze-dried in a sucrose matrix. 
594 Vertical/horizontal dotted lines indicate the threshold value of $\mathrm{a}_{\mathrm{w}}$ between the glassy and the 595 rubbery states, as well as the corresponding values of $\mathrm{Tg}$ and $\mathrm{m}$. Vertical/horizontal bold grey 596 lines indicate the values of $\mathrm{a}_{\mathrm{w}}$, Tg and $\mathrm{m}$ corresponding to the water monolayer coverage $\mathrm{M}_{\mathrm{M}}$ 597 (estimated from the BET equation). In bold under the $\mathrm{x}$ axis, are reported the values of the 598 temperature difference $\mathrm{T}-\mathrm{Tg}$, (with $\mathrm{T}=25^{\circ} \mathrm{C}$ ) corresponding to the $\mathrm{a}_{\mathrm{w}}$ values. 
Table 1

\begin{tabular}{|c|c|c|c|c|c|c|c|c|c|}
\hline & \multicolumn{2}{|c|}{ BET } & \multicolumn{3}{|c|}{ GAB } & \multirow{2}{*}{$\begin{array}{c}\mathrm{a}_{\mathrm{w}} \text { critical } \\
\left(\mathrm{Tg}=25^{\circ} \mathrm{C}\right)\end{array}$} & \multicolumn{2}{|c|}{ Gordon Taylor } & \multirow[t]{2}{*}{ References } \\
\hline & $\mathrm{M}_{\mathrm{M}}$ & $\mathrm{C}_{\mathrm{B}}$ & $\mathrm{M}_{\mathrm{M}}$ & $\mathrm{C}_{\mathrm{G}}$ & K & & Tgs & $\mathrm{k}_{\mathrm{GT}}$ & \\
\hline $\mathrm{LAB}^{\mathrm{a}}+$ sucrose & 3.67 & 13.53 & 4.87 & 3.80 & 0.97 & 0.241 & 66.3 & 7.6 & This work \\
\hline $\mathrm{LAB}^{\mathrm{a}}+$ fermented medium & & & 10.6 & 0.682 & 1.005 & 0.24 & 33.6 & 4.5 & (Fonseca et al., \\
\hline Fermented medium & & & 15.8 & 0.724 & 0.998 & 0.14 & 33.7 & 4.6 & 2001) \\
\hline $\mathrm{LAB}^{\mathrm{b}}$ & & & 8.7 & & & & & & (Selma et al., \\
\hline $\mathrm{LAB}^{\mathrm{b}}+\mathrm{M} 17$ broth & & & 11.8 & & & 0.083 & 50 & & 2007) \\
\hline $\begin{array}{l}\mathrm{LAB}^{\mathrm{b}}+\mathrm{M} 17 \text { broth }+ \text { protective } \\
\text { medium }\end{array}$ & & & 5.6 & & & 0.250 & 64 & & \\
\hline $\begin{array}{l}\mathrm{LAB}^{\mathrm{b}}+\mathrm{M} 17 \text { broth }+ \text { protective } \\
\text { medium + gelatine }\end{array}$ & & & 6.9 & & & 0.283 & 83 & & \\
\hline $\mathrm{LAB}^{\mathrm{c}}+$ lactose & & & & & & 0.26 & & & $\begin{array}{l}\text { (Higl et al., } \\
\text { 2007) }\end{array}$ \\
\hline $\mathrm{LAB}^{\mathrm{d}}+$ sucrose + MD 12 & & & & & & 0.145 & & & (Kurtmann et \\
\hline $\mathrm{LAB}^{\mathrm{d}}+$ lactose + MD 12 & & & & & & 0.228 & & & al., 2009b) \\
\hline Glucose & 5.4 & 0.3 & & & & & $31 / 36$ & 4.52 & (Zhang \& \\
\hline Dextran & 6.2 & 13.5 & & & & & 200 & & Zografi, 2000) \\
\hline Trehalose & 6.4 & 5.0 & & & & & 115 & & \\
\hline Starch & 6.6 & 17.9 & & & & & 225 & & \\
\hline Sucrose & $6-7^{*}$ & & & & & 0.236 & 62 & 5.42 & $\begin{array}{c}\text { (Roos, 1993, } \\
1997)\end{array}$ \\
\hline Lactose & 6.29 & 3.55 & 4.91 & 4.33 & 1.18 & 0.37 & 97 & 6.7 & (Jouppila \& \\
\hline Skim milk & 5.47 & 11.30 & 5.10 & 12.11 & 1.08 & 0.37 & 92 & 6.7 & $\begin{array}{c}\text { Roos, 1994a, } \\
\text { 1994b) }\end{array}$ \\
\hline Isolated Soy & 3.5 & & & & & & & & (Teng et al., \\
\hline Lipase & 5.1 & & & & & & & & 1991) \\
\hline Protein & $5-7$ & & & & & & & & (Costantino et \\
\hline Protein + trehalose & 5 & & & & & & & & al., 1998) \\
\hline
\end{tabular}

a Lactobacillus delbrueckii ssp. bulgaricus CFL1 
${ }^{\mathrm{b}}$ Streptococcus thermophilus S. Bo1 ; the protective mesium was composed of skim milk, sucrose and L-ascorbic acid.

${ }^{\mathrm{c}}$ Lactobacillus paracasei ssp. paracasei (F19)

${ }^{\mathrm{d}}$ Lactobacillus acidophilus (La-5), MD 12: maltodextin with a dextrose equivalent of 12.

* Estimated from (Costantino et al., 1998) 
Figure 1

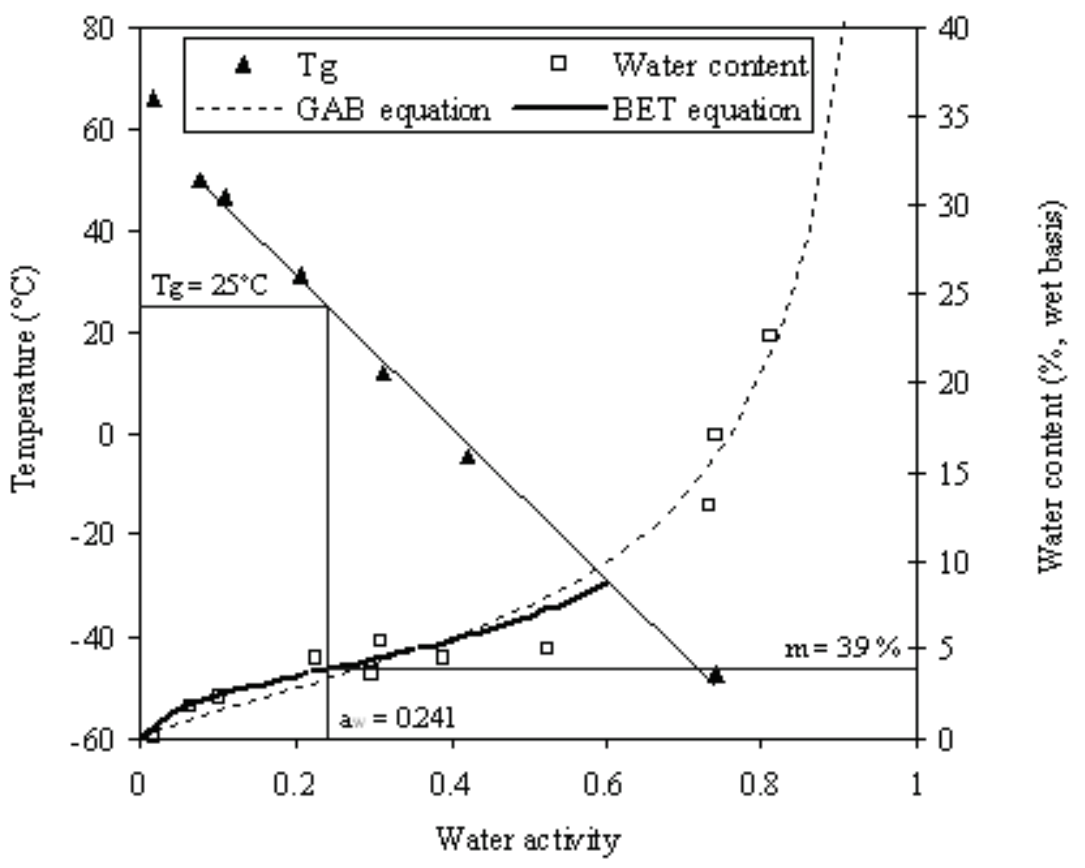


Figure 2

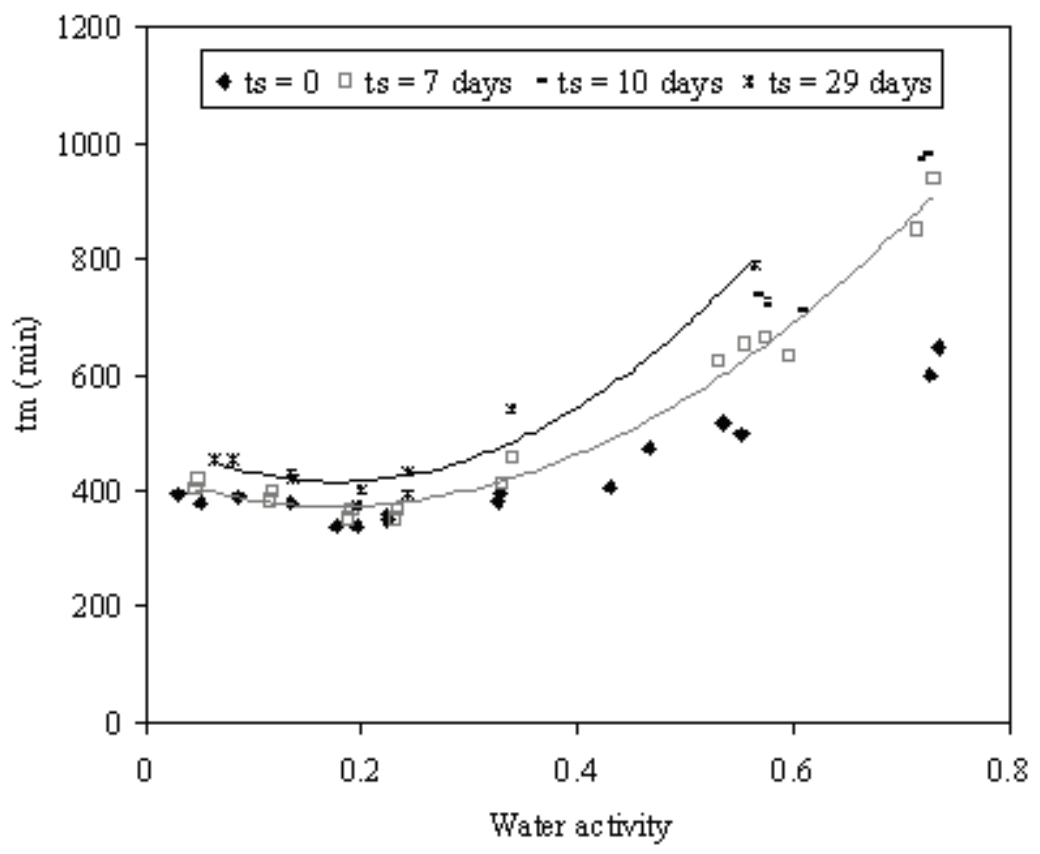


Figure 3

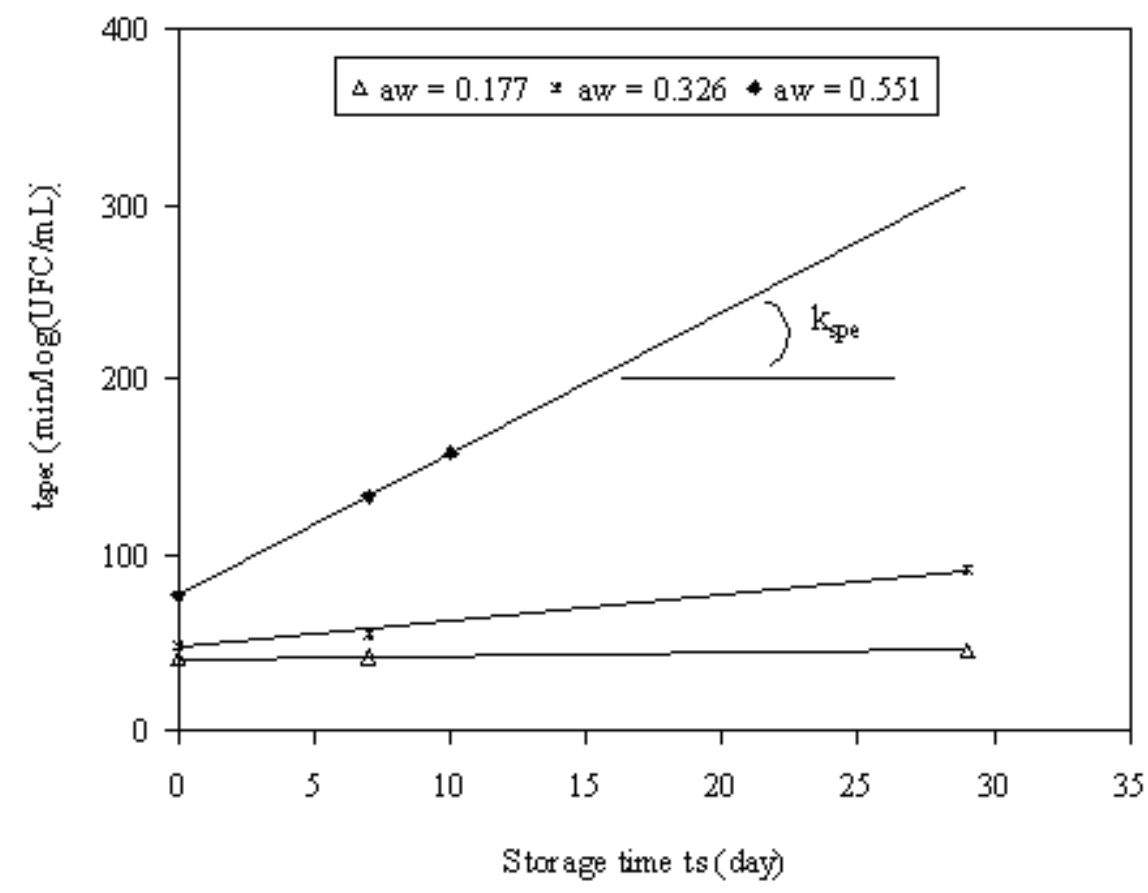


Figure 4

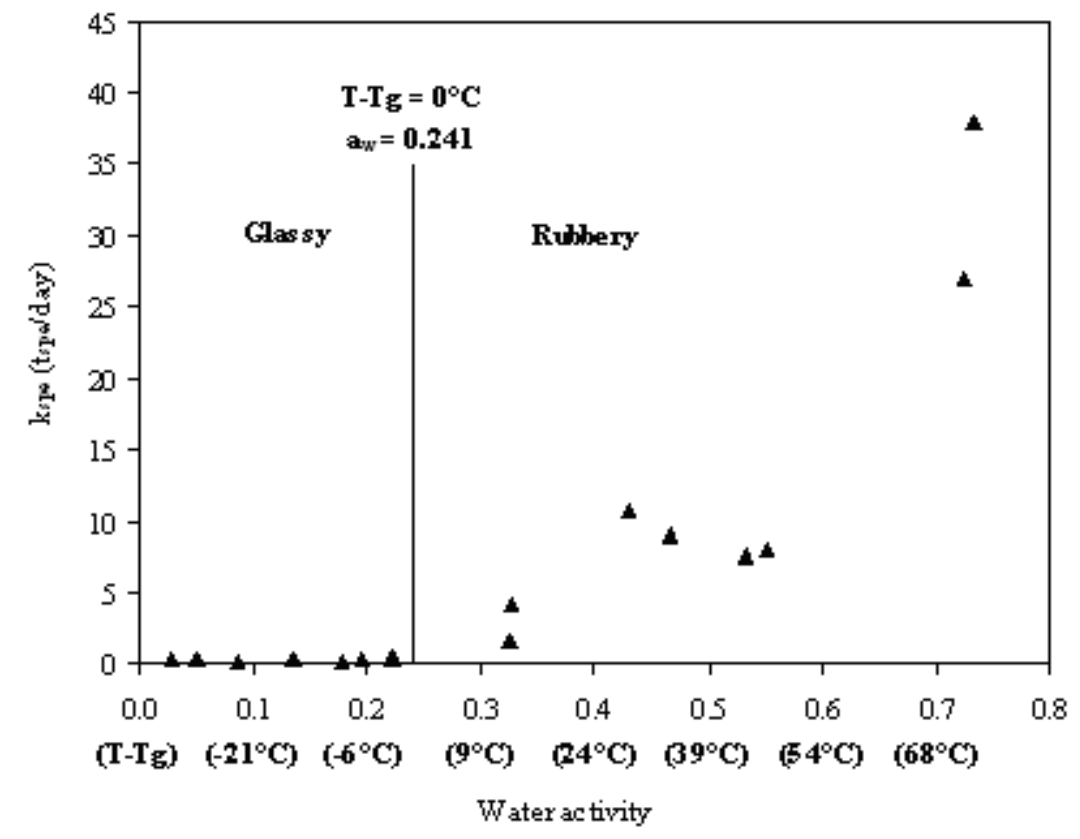


Figure 5

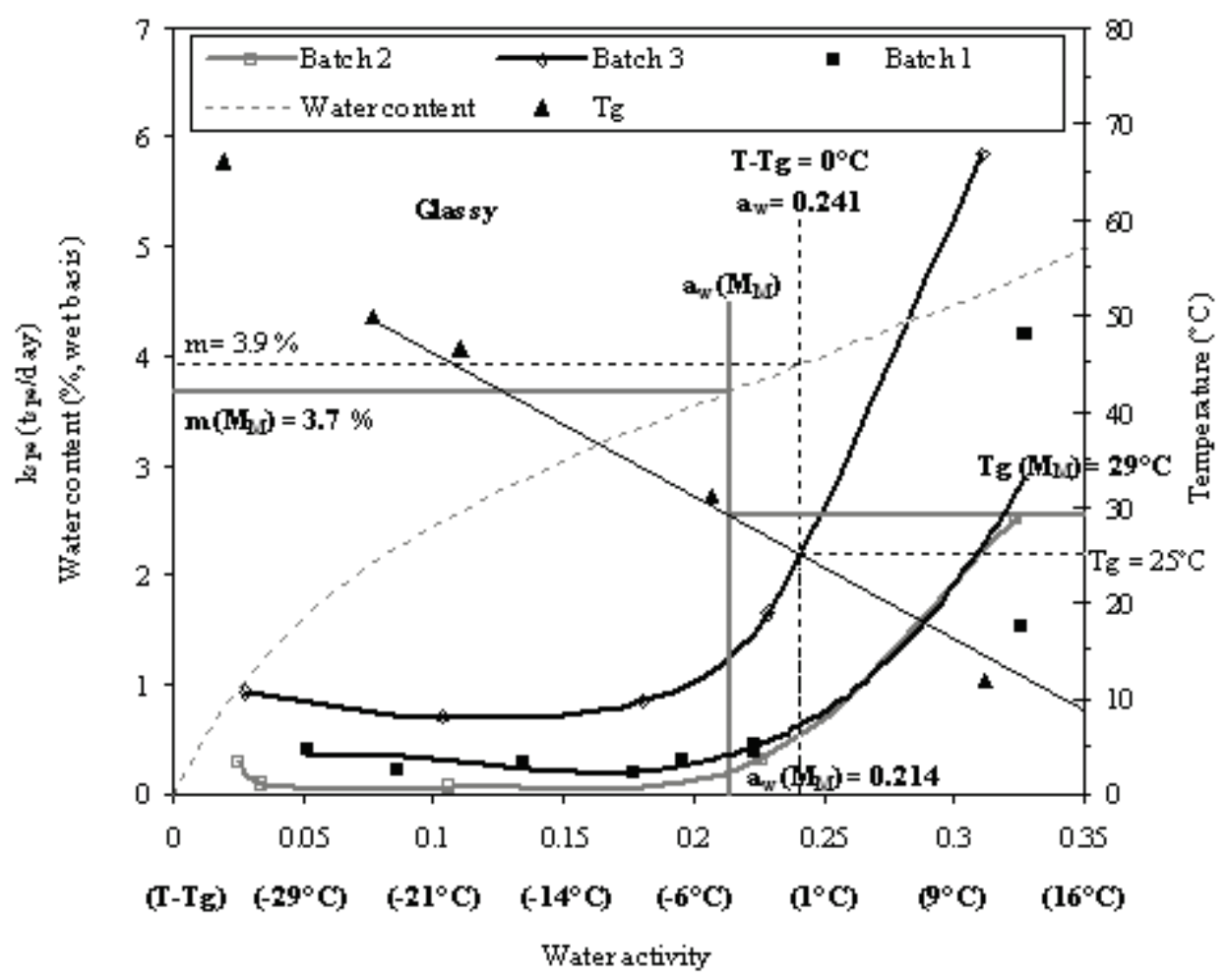

